УДК

94:725.94(497.6)"1921/1940"(093.2)

321.61:929 Карађорђевић П. I(093.2)

DOI https://doi.org/10.31212/tokovi.2020.1.duj.107-133

Оригинални научни рад

Примљен: 21. 4. 2019.

Прихваћен: 3. 9. 2019.

Sonja DUJMOVIĆ

Institut za historiju Univerziteta u Sarajevu sonja.dujmovic@iis.unsa.ba

\title{
Urbana kultura i kolektivno pamćenje - spomenik kralju Petru Oslobodiocu u Sarajevu
}

\begin{abstract}
APSTRAKT: Rad predstavlja pokušaj sagledavanja razloga za dugu, dvodecenijsku akciju podizanja spomenika Petru I Karađorđeviću u Sarajevu.

KLJUČnE REČI: spomenik, kralj Petar I Karađorđević, Sarajevo, urbana kultura, kolektivno pamćenje, urbana elita, kompromis, konsenzus, identitet
\end{abstract}

Među mnogim terminološkim odrednicama vezanim za pojam urbaninteta je i urbana kultura, jedan od složenih fenomena, višestrukog smisla i značenja, ali sa i zajedničkom odrednicom koju podrazumijeva spiritus urbanitatis, a to je kolektivitet i multiidentitet. Urbana kultura posjeduje i jednu značajnu integrativnu dimenziju, za kolektivni život nužni preduslov, a to je potreba za usaglašavanjem na malom prostoru u svakodnevnoj komunikaciji, potreba za tolerancijom, odlaganjem, ublažavanjem ili izbjegavanjem konfliktnih situacija.

Pristajanje na kompromis sa drugima u borbi za vlastite interese predstavlja i nudi dugoročne vrijednosti zajedništva, perspektivu harmoničnih odnosa i društvene pravde. Pristajanje na kompromis, tj. polovičnu pobjedu ili polovičan poraz, što kompromis jeste, u urbanoj sredini učesnike ne tjera na odustajanje od nekoga značajnog principa, ne potire viziju njihovog vlastitog identiteta, ne stvara im neprijatelje u njihovoj „vlastitoj“ grupi, pa su učesnici u kompromisu „samo instrumenti na kojima se, 
i kroz koje se, gradi jedna viša, dugotrajnija i apstraktnija vrijednost“. ${ }^{\text {.1 } U}$ tom smislu je gotovo dvodecenijska akcija postavljanja spomenika Petru I Karađorđeviću u Sarajevu govor o kompromisu i o društveno-političkom laviranju sarajevske urbane elite, kao i cjelokupnog građanstva u političkom sistemu Kraljevine SHS/Jugoslavije, ${ }^{2}$ ali i kontinuiranom porazu integralističke politike, čiji je izraz trebao biti sām spomenik.

Sljedeća terminološka odrednica značajna za razumijevanje ove međuratne akcije je kolektivno pamćenje, pri čemu je možda izlišna napomena da pamćenje i sjećanje nisu sinonimi. Kolektivno pamćenje, za razliku od sjećanja pojedinca koje predstavlja pojedinačni odnos prema događajima iz prošlosti, ovisi o ideološkim, klasnim, baš kao i rodnim obilježjima pojedinca ili grupe. ${ }^{3} \mathrm{U}$ širem smislu pamćenje je kolektivna odluka, društveno određena, i predstavlja smišljenu, kontrolisanu i usmjeravanu upotrebu prošlosti, tako da se pojavljuje kao dio kulturnog identiteta i odnosi se na dio integrativnog znanja koji oblikuje sliku prošlosti grupe, pri čemu se određuje šta treba a šta ne treba pamtiti, odnosno zaboraviti. Kolektivno pamćenje dakle „predstavlja mozaik izabranih sadržaja značajnih za opstanak i integraciju grupe, te za očuvanje grupnog identiteta“. ${ }^{4}$ Ukoliko i ne postoje integrativni sadržaji u prošlosti, poželjna slika prošlosti se može konstruisati i sa njom uspostaviti „kontinuitet“. Za proizvodnju ili izbor tradicije u svrhu izgradnje političke imaginacije zajedništva, a naročito u slučaju vjersko-nacionalnih složenih društava i sredina, potreban je, pored ostalog, i minimum konsenzusa elite, pa i na lokalnom nivou, ali i zajednička vizija budućnosti i napretka društva.

Sagledavajući sažeto ova višedimenzionalna i složena dva pojma - urbana kultura i kolektivno pamćenje - moguće je ipak uočiti njihove osnovne zajedničke karakteritistike: kolektivitet, urbanitet, zajednički identitet i kompromis, čiji glavni nosioci mogu da budu samo djelujući u pluralitičkom prostoru - građani, odnosno urbana elita.

1 Dražen Pehar, „Urbani duh kompromisa i postdaytonska Bosna“, Forum Bosnae, br. 5, (Sarajevo, 1999), 10.

2 Više o spomenicima podizanim Petru I Karađorđeviću: Olga Manojlović Pintar, Arheologija sećanja, spomenici i identiteti u Srbiji 1918-1989, (Beograd: Udruženje za društvenu istoriju, Čigoja štampa, 2014), 263-265.

3 Renata Jambrešić-Kirin, Dom i svijet, (Zagreb: Centar za ženske studije, 2008), 10.

4 Sandra Radenović, ,Nacionalni identitet, etnicitet, Kritička kultura sećanja“, Filozofija i društvo, br. 31 (3), (Beograd: Institut za filozofiju i društvenu teoriju, 2006), 234.

5 Više o tome: Izmišljanje tradicije, ur. Erik Hobsbom, Terens Rejndžer, (Beograd: Biblioteka XX vek, 2002). 
Ove uvodne natuknice značajne su za razumijevanje djelovanja akterâ na podizanju spomenika Petru I Karađorđeviću u Sarajevu, koje ujedno oslikavaju društveno-istorijski kontekst, ali su i indikatori uspješnosti politike stvaranja zajednice „troplemenog naroda“, potom integralističkog jugoslovenstva, legitimacije državnih institucija Kraljevine SHS/ Jugoslavije i novouspostavljenog sistema njenih društvenih vrijednosti.

Povod za pokretanje inicijative za podizanje spomenika bio je momenat kada je kralj Petar I Karađorđević (1844-1921) 16. augusta 1921. godine „zamenio ovaj život boljim“. Kako štampa izvještava, Sarajevo je bilo u žalosti, gradsko poglavarstvo izdalo plakate sa tužnim saopštenjem, radnje su zatvorene, organizovane su molitve u bogomoljama, oficiri i „narod bez razlike vere, sokoli i sokolice" prisustvovali su komemorativnim svečanostima, na zgradama izvješene crne zastave, pored već organizovanih delegacija $^{6}$ pojedine srpske institucije spremale su delegate za sahranu, ${ }^{7}$ a muslimanski ministri prekinuli su proslavu drugog dana Kurban-bajrama spremavši se na put za Beograd, dok su bajramski topovi po odluci kotarskog vakufskog povjerenstva i džematskog medžlisa prestali pucati. ${ }^{8}$ Ministarski savjet je najavio državnu žalost u trajanju od šest mjeseci, od kojih će prvih šest nedelja trajati duboka žalost. ${ }^{9}$

U to vrijeme Sarajevo je bilo dio jednog postratnog društva, vjerski i etnički kompleksno i u tranziciji, ${ }^{10}$ politički šaroliko, a struktura lokalne zajednice nedovršena. Sve ove karakteristike pružaju sliku jednog složenog urbaniteta i uslova za karakter bilo koje zajedničke aktivnosti. Uz to, to je vrijeme nakon netom usvojenog Vidovdanskog ustava, proglašenja Zakona o zaštiti države, vijesti o nasilju nad muslimanskim stanovništvom u Sandžaku, ${ }^{11}$ te formiranja Hrvatskog bloka, čime su stvoreni svi preduslovi za početak iscrpljujuće političke borbe na državnoj razini, a što naravno nije moglo zaobići ni Sarajevo.

U svakoj, pa i u ovakvoj društveno-političkoj konstelaciji, kultura jeste i ostaje funkcionalna u mjeri u kojoj je odraz vrijednosti elite, te je

$6 \quad$ Hrvatska sloga, br. 180, (Sarajevo), 21. kolovoz 1921, 3.

7 Srpska riječ, god. XVII, br. 168, (Sarajevo), 20. avgusta 1921, 3.

8 Pravda, god. III: br. 85a (323), (Sarajevo), 17. augusta 1921, (12. Zil Hidže 1339), 2; br. 89 (327), 27. avgust 1921, 3.

9 Narod, god. I: br. 36, (Sarajevo), 24. avgust 1921, 1; br. 37, 27. avgust 1921, 2.

10 Prvi popis u Kraljevini iz 1921. godine govori o brojci od 66.317 stanovnika, od čega muslimana 22.474 (33,88\%), rimokatolika 19.242 (29,01\%), pravoslavnih 16.468, (24,83\%), Jevreja 7.458 (11,24\%) i grkokatolika 160. Definitivni rezultati popisa stanovništva, Kraljevina Jugoslavija, (Sarajevo, 1932).

11 Pravda, god. III, br. 86 (324), 20. august 1921, (15. Zil hidže 1339), 2. 
time njeno promovisanje i oblikovanje proizvod volje vlasti - iste one šarolike strukture, multikulturnog karaktera - koja treba da stvori poželjni kulturni ambijent, kako u odnosu na upravno-administrativne komponente Kraljevine, a koje su se nalazile u vremenu preraspodjele političke, sociološke i prostorne dimenzije, ali jednako važno, tako i kulturni identitet urbane zajednice kao pretpostavke održivog urbanog razvoja, odnosno da iskaže volju i vlasti i građana u javnom životu grada.

Gradska elita Sarajeva, u političkom smislu neusklađenog programa, vizije i djelovanja, dakle, nehomogena, ovoga puta spomenikom, vizuelnim govorom, trebala je da u javnom prostoru koji predstavlja zajedničko dóbro, ono što ne pripada nikome, odnosno pripada svim građanima grada „kao prostor uključivanja i izmirenja svih konflikata“ $\mathrm{i}$ „u kojem bi trebalo doći do racionalnog, ne-prisilnog konsenzusa" ${ }^{12}$ pošalje svoje nove poruke, dok se u tom momentu neželjena baština briše. ${ }^{13}$ Jednoglasno usvojenom inicijativom odbornika Jove Pešuta na sjednici sarajevske opštine i zaključkom prezidijalne sjednice od 29. augusta 1921, sazvana je anketa svih kulturnih, humanitarnih i viteških društava grada 19. septembra u Gradskoj vjećnici, „glede postignuća vidnog znaka blagodarnosti blagopokojnom Kralju Petru I", 14 gdje je 28 društava „jednodušno“ bilo za podizanje spomenika. ${ }^{15}$ Jednoglasno je odlučeno i da predsjednici četi-

12 Bojana Pejić, Javni rezovi, datum pristupa 3. 5. 2011, http://www.kulturpunkt.hr/ content/javni-rezovi

13 O uklanjanju spomenika Franji Ferdinandu kao „vidoj uspomeni“ „na naše robovanje“ i spomen-ploče sa kuće preko puta spomenika: Narodno jedinstvo, god. I, br. 58, (Sarajevo), 6. marta 1919, 3. - Spomenik (bista) F. Ferdinanda poslat je „pokojnikovoj familiji u Konopište, a stubovi i ostalo u muzej." Srpska riječ, god. XV, br. 7, 9/22. mart 1919, 3. Više o tome: Indira Kučuk-Sorguč, „Prilog historiji svakodnevnica: Spomenik umorstva - okamenjena prošlost na izdržavanju stoljetne kazne“, Prilozi, br. 34, (Sarajevo), 2005.

14 Na anketu je gradska opština 14. septembra 1921. godine pozvala kulturna, humanitarna i viteška društva: Prosvjeta, Hurijet, Dobrovoljna zadruga Jugoslovenki, Gajret, Hrvatski klub, Kolo srpskih sestara, La Benevolencija, El-Kamer, Napredak, Podružnica Jugoslavenske matice, La Gloria, La Humanidad, Ezrat jetomin, Sloga, Trebević, Lira, Trgovačko udruženje za grad Sarajevo, Srpska trgovačka zanatlijska omladina, Udruženje jugoslovenskih inžinjera i arhitekata, Jugoslovensko novinarsko udruženje, Savez dobrovoljaca, Sokolsko društvo, Slovenski klub, Udruženje ratnih invalida, Jugoslavenski klub, Kolo jahača Regent Aleksandar, Društvo Hrvatski radiša, Društvo umjetnika, Srpska pravoslavna crkvena opština. Arhiv Bosne i Hercegovine (ABiH), Fond Odbor za podizanje spomenika kralju Petru I u Sarajevu (OPSKP), kut. 1, dok. 11/1921.

15 Mišljenja su izdvojili Milan Ćurčić ispred Srpskog pjevačkog društva Sloga i dr Niko Andrijašević ispred Društva umjetnika koji su bili za podizanje zgrade za koncerte i izložbe koju Sarajevo nema, te predstavnik Udruženja invalida koji je bio za ustanovljavanje humanitarne zaklade. ABiH, OPSKP, kut. 1, dok. 12/1921. 
ri najznačajnija kulturna društva (Prosvjeta - Sima Mirković, Gajret - Alija Kurtović, Napredak - Aleksa Đebić, La Benevolencija - Isidor Sumbul) predlože širi radni odbor. Na skupštini organizovanoj 28. septembra, gdje je bilo prisutno 40 sarajevskih društava, odlučeno je i da se pozovu predstavnice „svih gospojinskih društava“. 16

Među odlukama koje su slijedile bila je ona o mjestu postavljanja spomenika kralju Petru I Karađorđeviću Velikom Oslobodiocu. Preovladalo je mišljenje da to bude pred „pred oficirskim domom“.17 Konkretan prijedlog još na prvoj sjednici izabranog odbora podnio je predsjednik srpsko-pravoslavne crkvene opštine, da se za spomenik, „prvi u Sarajevu“, prokrči novi trg „u kompleksu starih trošnih kuća između Šljivine ulice i portala nove srpske pravoslavne crkve",18 budući da je redovna oktobarska skupština srpsko-pravoslavne opštine te 1921. godine završila svoj rad zaključkom „da će bez ošteta ustupiti svoje zemljište na kome je gradski kolodvor, ako to učine i ostali okolišni vlasnici i ako će se podići spomenik na tom mestu kralju Petru“. ${ }^{19}$ Time su u stvari počele dugogodišnje rasprave o pravljenju prostora za centralni sarajevski trg i njegovom izgledu, ${ }^{20}$ kojim će Sarajevo dobiti „ne samo svoj najljepši ukras, nego i prostrani trg, koji će biti od velike i neprocjenjive urbanističke, arhitektonske i higijenske vrijednosti“.21 Ipak, devet godina nakon osnivanja odbora i markiranja mjesta za trg, rasprava je velikim dijelom bila okrenuta carinarnici koja se nalazila na tom prostoru, njenoj novoj lokaciji i načinu obezbjeđenja sredstava za njeno preseljenje, ${ }^{22}$ a u konačnom izvještaju

16 Poziv se odnosio na Kolo srpskih sestara, Dobrotvornu zadrugu Jugoslovenki, Jevrejsko gospojinsko društvo La Humanidad, žensku podružnicu Napretka, žensku podružnicu Gajreta i Muslimansko žensko društvo Osvitanje.

17 Narod, god. I, br. 37, 27. avgusta 1921, 2.

18 Srpska riječ, god. XVII, br. 190, 20. septembra 1921, 3.

19 Narod, god. I, br. 59, 8. novembar 1921, 2. - Radilo se o zemljištu između ulica Kralja Petra, Ferhadije, Preradovićeve i zgrade nove srpsko pravoslavne crkve. ABiH, OPSKP, kut. 1, dok. 111/1923.

20 Jugoslovenska pošta, god. IX, br. 2418, (Sarajevo), 16. maj 1937, 5.

21 Izvještaj predsjednika odbora Šćepana Grđića od 5. oktobra 1938. godine. Šćepan Grđić, „Spomenik Kralja Petra Oslobodioca u Sarajevu”, Kalendar Prosvjeta za godinu 1939, (Sarajevo, 1939), 46.

22 Jugoslovenska pošta, god. II, br. 278, 24. aprila 1930, 3. - Problem ipak nije bio tako jednostavan. Na osnovu izvještaja Odbora 24. novembra 1932. može se iščitati da su carinarnicu pratila tri zahtjeva za eksproprijaciju zemljišta, dvije neuspješne licitacije, storiranje zajma od Hipotekarne banke za gradnju nove a na molbu gradske opštine, nelikvidnost banaka u koje je uložen novac za spomenik po osnovu člana 5 Zakona o zaštiti zemljoradnje, brojne intervencije ministrima, pa i predsjedniku vlade, optuživanja Odbora i samog predsjednika za nedovoljno zalaganje u radu. U 
Odbora carinarnica će eufemistički biti označena kao glavni kamen spoticanja u izgradnji trga. U pozadini su stajali vlasnički odnosi, jer se u izvještaju Odbora 1938. godine pominje: „zaključeno je da se umoli Gradska opšina da se požuri poslom oko podizanja trga, i da nađe sredstva za esproprijaciju zemljišta i zgrade Vakufa Ajas pašine džamije i Evladijet Vakufa Semiz, pošto su druga dva vlasnika zemljištâ i zgrada na tom mjestu: srpska pravoslavna opština i državni erar svoja zemljišta besplatno ustupila, što sve iznosi pet dunuma od osam koliko iznosi cijelo zemljište", za koje je prikupljeno i obećano $2.299 .780,41$ dinar. ${ }^{23}$ Stvari su se sporo odvijale, pa je tek decembra 1940. godine Gradsko poglavarstvo raspisalo licitaciju za rušenje svih otkupljenih objekata na trgu, a još se za vlasništvo Semizova evladijet vakufa očekivalo konačno sudsko riješenje. Rušenje je u tom momentu obuhvatalo kuću srpske crkvene opštine sa četiri manja objekta i Bašagićevu kuću sa knjižarom..$^{24}$ Po predviđenim nacrtima trg je trebao iznositi preko šest hiljada kvadratnih metara. ${ }^{25}$

Nastojanje oko formiranja trga, koji do tada Sarajevo nije imalo, zadirući u zatečeni prostorni poredak grada, naznačilo je izmjenu forme vladanja države i nova usmjerenja društvene i političke hijerarhije. Potreba da se pokrene uobličavanje društvene kohezije i strukturiše poželjni identitet, a time usađivanje novih sistema vrijednosti, osjećanja identifikacije sa novostasalom zajednicom, svijesti o potrebi njegovanja patriotizma, zahtijevala je trg, sa mogućnošću javnog promovisanja društveno poželjnih ideja. Trg je istovremeno, kao u svakoj urbanoj sredini, trebao predstavljati i prostor komunikacije, slobode izražavanja za sve kojima je bilo tijesno u oformljenim socijalnim, nacionalnim i političkim okvirima i time potencijalno riskantan za postojeće političke strukture. S obzirom na stav pojedinih članova odbora da je sa novim političkim okvirom došla i sloboda, a da "grad Sarajevo nije nikada živilo slobodnim životom, pa usljed toga i nema nikakvog spomenika, te treba, da ima ovakav spomenik slobode i oslobođenja“, ,jer trg nam je potreban kao i spomenik“, kome se

tom momentu Odbor je raspolagao sa sumom od nešto preko 2,7 mil. dinara. $\mathrm{ABiH}$, OPSKP, kut. 1, dok. 60/1932.

23 Narod, god. IV, br. 26, 9. april 1924, 2. - Međutim, na osnovu zaključka vakufsko-mearifskog sabora od 2. januara 1925. godine, upućen je dopis Odboru za podizanje spomenika „da se po propisima Šeriata ne mogu vakufska dobra poklanjati“. O visini kirija koje je Vakuf ubirao od objekata i zemljišta: ABiH, OPSKP, kut. 1, dok. 7/1925, 16/1926, dok. 60/1932; Jugoslovenska pošta, god. X, br. 2680, 23. mart 1938, 4.

24 Jugoslovenski list, br. 287, (Sarajevo), 4. decembar 1940, 5. - Rušenje je uslijedilo 22. decembra. Jugoslovenski list, br. 302, 21. decembra 1940, 5.

25 Grđić, „Spomenik Kralja Petra Oslobodioca“, 44-46. 
i može zahvaliti da će nastati trg, u spisima Odbora se budući prostor za spomenik naziva i „Trg Oslobođenja“.26

Za regulaciju trga povedena je rasprava tek 24. aprila 1933, a na inicijativu dr Nike Andrijaševića raspisan je „internacionalni natječaj“. ${ }^{27} \mathrm{Za}$ osnovu uređenja uzeta je skica prvonagrađenog Josipa Pičmana, ${ }^{28}$ ali ne u potpunosti, nego samo riješenje dijela trga pred crkvom, odnosno južnom polovinom trga, gdje je paralelno sa cestom planirana mala „aleja visokih drveta“. „Prostor u aleji između redova drveta, treba da je popločan, kao i ostali dio trga, da tlo cijelog trga dobije jedinstven izgled, i da se između

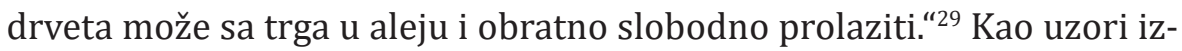
gradnje dijela trga ispred bogoslovije prihvaćeni su nagrađeni plan Mate Bajlona $^{30}$ i pohvaljene skice broj 5 pod lozinkom „189534“, koje su uključivale kolonade, „najljepše izvedene u ta dva nacrta (...) praktične, što su jeftinije, i što je glavno, što vode računa o zahtjevu SPO: da joj se besplatno ustupi onaj dio prostora koji ostane između kolonada i bogoslovije, kako bi na tome mjestu digla koristonosne objekte, kao naknadu za poklonjenih $1.500 \mathrm{~m}^{2}$ zemljišta na trgu“. ${ }^{31}$ Sa zapadne strane trga planirane su „prostorije za različite izložbe, na način kako je g. Bajloni na svom nacrtu te izradio“. Ovako izgrađen trg, po mišljenju Odbora, ${ }^{32}$ i kad se još na njemu podigne spomenik, biće „ures grada Sarajeva kakve se samo poželeti može, zadovoljiće potrebama grada, a biće za sva vremena veličanstveni izraz zahvalnosti naroda Bosne i Hercegovine prema Kralju Petru Oslobodiocu“.33

26 ABiH, OPSKP, kut. 1, dok. 12/1921, 60/1932.

27 Prva nagrada je iznosila 20.000 din, druga 10.000 i treća 5.000 dinara. ABiH, OPSKP, kut. 1, dok. 23/1933.

28 Josip Pičman (1904-1936), arhitekta, jedan od predstavnika hrvatskog modernog arhitektonskog usmjerenja, autor tridesetak projekata, član Radne grupe Zagreb.

29 Andrija Mutnjaković, „Arhitekt Josip Pičman“, Život umjetnosti, 14, (Zagreb), 1971, 83, datum pristupa 20.11. 2015, https://www.ipu.hr/content/zivot-umjetnosti/ ZU_14-1971_074-089_Mutnjakovic.pdf

30 Mate Bajlon (1903-1995), arhitekta i od 1947. profesor na Arhitektonskom fakultetu u Beogradu. Jedno vrijeme je radio kao opštinski arhitekta u Sarajevu do II svjetskog rata.

31 Izrada idejnih skica povjerena je arhitektama Vasi Todoroviću, Bajčetiću, Kadiću, Šamaneku, Kabilju i Finciju. Jugoslovenska pošta, br. 3540, 14. januar 1941, 4.

32 Ocjenjivački sud za projekat uređenja trga činili su: Asimbeg Mutevelić, gradski načelnik, Šćepan Grđić, predsjednik Odbora, dr Niko Andrijašević, član Odbora i predstavnik Društva umjetnika, inž. Đorđe Božić, šef gradskog građevinskog odjeljenja, inž. Oskar Grof, direktor Srednje tehničke škole, inž. Marcel Martinis, prof. Srednje tehničke škole, ing. Solaković Ismet; zamjenici: dr Ivan Pavičić podnačelnik, dr Jakob Kajon, advokat, inž. Miloš Skakić, inž. Sejfudin Muftić, Miloš Miladinović, građevinski poduzetnik. ABiH, OPSKP, kut. 2, dok. 18/1937.

33 Sa sjednice Odbora 3. maja 1934. ABiH, OPSKP, kut. 1, dok. 16/1934. 
Kakav spomenik je trebalo podići na tom javnom prostoru - trgu i kakve vrijednosti je trebalo da promoviše u društvu koje je doživjelo dramatične političke transformacije, duboke društvene i socijalne promjene i izmjenu okruženja? Spomenik kralju je zamišljen kao centralno mjesto oko koga će se u narednim godinama odvijati manifestacije jedinstvenog nacionalnog duha „troplemenog naroda“. Idući u tom smjeru nije trebao oličavati dominantne vrijednosti tadašnjeg društva, nije idejno promovisao muške ideale snage, heroizma, patriotizma, otpora i muškog žrvovanja. Riječima predsjednika Odbora: „Prije svega Odbor hoće da spomenik prikazuje Kralja Petra kao Kralja, sa svim Kraljevskim dostojanstvom. Mi ne želimo da prikažemo Kralja Petra kao junaka, koji poteže mač iz korica, kao na spomeniku u Bečkereku, a još manje kao junaka koji je mač izvukao i njime zamahnuo, kao na spomeniku u Bijeljini. Junaštvo je osnovna odlika naše rase, i baš zbog toga obična stvar. U nas u Bosni i Hercegovini ima ne samo u svakom srezu, nego u svakom selu junaka, i to ne samo junaka po svojim ličnim svojstvima, nego junaka, danas iza balkanskog i svjetskog rata, i po svojim djelima, a osim toga i junačkih žrtava na sve strane. Zbog toga je junaštvo obična pojava, koja se cijeni, ali koja kod Kralja Petra nije najglavnija. (...) Da se ne bi natjecatelji uzalud mučili prikazujući Kralja Petra drukčije, mi smo to u natječaju istakli.."34 „Glavna odlika Kralja Petra koja ga je učinila oslobodiocem je sasvim druge prirode. Kad je Petar Karađorđević došao na prijestolje, i položio zakletvu na ustav, odjednom su prestala u Srbiji sva trvenja između naroda i Krune, koja su bila stalna pod vladom posljednjih Obrenovića. Volja Kralja Petra i volja naroda postale su jedna volja, suverenitet naroda i suverenitet kralja jedan suverenitet (...) Eto ta odlika Kralja Petra, odlika koja kod kraljeva nije česta, da je bio potpuno jedne volje sa svojim narodom, da je bio i najjači izraz narodne volje, ta odlika učinila je od njega kralja Oslobodioca." ${ }^{35}$ Uspostavljanje ovakve slike kralja, koji u suštini nije tradicijom imao svoje mjesto u gradu, građenje njegovog identiteta u pravcu zaštitnika svih građana „troplemenog naroda“ činilo se jedino mogućim i opravdanim.

Ovu namjeru Odbora pokazuje i njegov proglas upućen svim Bosancima i Hercegovcima. „Ujedinivši skoro sve dijelove naroda Srba, Hrvata i Slovenaca i spojivši skoro sve krakove u kojima taj narod živi u jedan slobodan državni organizam Kralj Petar izvršio je veliko djelo ujedinjenja i oslobođenja o kome su sanjali i na kome su radili najbolji i najveći ljudi

34 Pismo Šćepana Grđića Anti Meštroviću 6. decembra 1937. godine. ABiH, OPSKP, kut. 2, dok. 51/1937.

35 Sa sjednice Odbora 22. septembra 1938. ABiH, OPSKP, kut. 2, dok. 5/1941. 
naše nacije. Nikad ni jedan vladalac naše krvi nije ni pokušao a kamo li izvršio djelo kojem bi se veličina mogla mjeriti sa djelom Petra I Krađorđevića. Ni Tomislav, ni Časlav, ni Krešimir IV, ni Nemanja, ni Dušan Silni, ni Tvrtko niti i jedan drugi od velikih vladara naše prošlosti, koji su se odlikovanli radom na ujedinjavanju nije spojio toliko dijelova našeg naroda zajedno, niti je u jednu državu sastavio toliko krajeva naše lijepe i prostrane otadžbine. (...) Pokažimo u ovom vremenu grubog materijalizma da idealizam, stare vrline naše, nije nestalo u našim redovima, pokažimo da nam zahvalnost nije prazna riječ nego djelo!" Takvo viđenje kralja i izgradnje spomenika u tom momentu je podržao i nacionalno šaroliki odbor, ${ }^{36}$ i pored značajnih zamjerki predsjedniku Šćepanu Grđiću. ${ }^{37}$ Spomenik je trebao označavati ustoličenje kralja Oslobodioca u Bosni, obilježiti i osnažiti političke teritorije nove države. U konačno izabranoj verziji „Na spomeniku je pretstavljen Kralj Petar kao kralj, sa kraljevskim znacima: plaštom i krunom i sa skiptrom podignutom u ruci prema neoslobođenim krajevima, kuda simbolički upućuje oslobodilačku vojsku", a čime su bili „Svi zadovoljni“. ${ }^{38} \mathrm{U}$ ovoj predstavi vladarski genij je dakle vojevao riječju i perom za slobodu i ustavnost zemlje, čime je Odbor načinio značajan

36 Proglas je upućen 27. parila 1922. godine. Potpisnici su bili Šćepan Grđić, predsjednik, dr Srećko Perišić i Fehim Spaho, potpredsjednici, Lujo Dvorniković i dr Jakob Kajon - tajnici, Muhamed Hadžialić, blagajnik, te odbornici: Albert Abinun, Anto Alaupović, Silvio Alkalaj, dr Niko Andrijašević, Franjo Baković, Isak Baruh, Ilka Bem, B. Buhvald, Milan Ćuković, Vladimir Dević, Jakub Filipović, Aleksa Đebić, Ljubo Đurđić, Mujaga Hadžibaščaušević, Uzeir Hadžihasanović, Tanasije Ikonić, Angela Ivošević, Rafael Izrael, Jozef Kajon, Alija Kurtović, Simo Mirković, Ivan Mitrović, Justina Neferović, Ljubo Nikolić, Mara Pavlović, Mijo Poljak, Milan Pupić, Juraj Sočo, Nikola Stojkanović, Dževad Sulejmanapašić, Isidor Sumbul, dr Zaim Šarac, Jozo Udovčić. ABiH, OPSKP, kut. 1, dok. 31/1922.

37 Šćepan Grđić je nakon rata bio šef prosvjetnog odjeljenja Zemaljske vlade i protiv njegovog djelovanja je Pravda, organ Jugoslovenske muslimanske organizacije, često pisala. Za predsjednika Odbora ga je predložio Jakub Filipović, trgovac, 5. oktobra 1921. na sastanku Odbora. ABiH, OPSKP, kut. 1, dok. 15/1921.

38 Jugoslovenska pošta, god. XII, br. 3294, 2. mart 1940, 5. - Prvobitnu ideju da spomenik treba biti „okrenut od istoka prema zapadu, u pravcu kojim je došla oslobodilačka srpska vojska“ korigovao je A. Meštrović primjedbom „da je ta dispozicija sa umjetničke i urbanističke tačke gledišta potpuno pogrešna, a evo zašto: Prema priloženim nacrtima i Vašem opisu, zasađeni i nezasađeni dio trga sačinjavaju jednu cjelinu, kojoj je centar i glavni ures (idejni smisao) sam spomenik. Prema tome, zasađeni dio trga može biti samo podređena pozadina, a ne neki objekat (pa i ako ne zidani), koji je položen paralelno sa spomenikom, kao da imaju jednak zadatak i značaj." Prema ovome, da bi zasađena aleja bila pozadina spomenika, treba da spomenik bude okrenut prema sjeveru, ukoliko se ostane pri mjestu spomenika u sredini trga. - $\mathrm{ABiH}$, OPSKP, kut. 2, dok. 5/1941. 
iskorak u dotadašnjoj praksi, ${ }^{39}$ on je posjedovao legitimitet vlasti. Naglašena je ideja časti monarha, personifikacija uspostavljanja pravde i mira, ravnoteže i reda u domovini, čime ujedinjuje nacionalnu zajednicu i teritoriju, ali koja je u Kraljevini, u Sarajevu, a naročito sa proglašenom idejom jugoslovenskog unitarizma bila „inkompatibilna sa idejom nacionalne unifikacije“. ${ }^{40}$ Pri tome se potvrđivala ideja da kralj nije samo vojnik nego i onaj koji pravednošću osigurava blagostanje svojim podanicima. Zauzvrat, njegova položena žrtva oslobođenju neće biti zaboravljena, što podanici, izražavajući zahvalnost, i spomenikom potvrđuju. ${ }^{41}$

Ko je bio Petar I Karađorđević? Za demokrate je on prevodilac Stjuarta Mila (O slobodi), građanin „kalvinske i republikanske Ženeve“, uz koga je „sloboda i ustavnost Srbije trebala da postane zajednička svojina jugoslavenska", 42 ,još od pre poznat kao prijatelj gonjenih i tlačenih, proširio je i povećao svoj zavet, doneo je pravdu i slobodu svim Srbima, Hrvatima i Slovencima (...) Petar je doista bio verni pastir svog stada koje ni u najvećoj opasnosti nije ostavljao". ${ }^{43} \mathrm{U}$ odnjegovanom sjećanju nakon 1918. godine za većinu srpskog naroda Petar je Mrkonjić, prisutan već 40 godina kao „krajiški ustaša“, vlastitim izborom žrtva „za dobro raje“ ${ }^{44}$ mada je istorijska realnost bila nešto drugačija. ${ }^{45}$ Njegovo ustoličenje na srpskom prijestolu 1903. popratila je sarajevska Bosanska vila tekstom „Njegovo Veličanstvo kralj Petar I" sa slikom na kojoj je kralj sa sabljom i u uniformi, ${ }^{46}$ a sljedeće, 1904. godine tekstom „Heroj“ Koste Majkića i slikom zajedno ovjenčanih Karađorđa Petrovića i i njegovog potomka kralja Petra. ${ }^{47}$

Za ostale Sarajlije kralj Petar je zamjenio Franju Josipa u nazivu glavne ulice i glavne kasarne u gradu decembra 1918. godine. ${ }^{48} \mathrm{Kralju}$, koji

39 „Srpske regalije pre Petra I, kao i one potonje Kraljevine SHS i Kraljevine Jugoslavije, nisu precizno definisane sve do 30-ih godina 20. veka“. Dragomir Acović, „Regalije“, datum pristupa 31. 11. 2015, http://www.pokimica.com/lang_lat/tekst2_04_lat. htm

40 Senadin Musabegović, „Upotreba simbola i korištenje mita“, Dijalog, časopis za filozofiju i društvenu teoriju, br. 1-2, (Sarajevo), 2007, 112.

41 Bilo je i glasova protiv ovakvog imenovanja kralja. Srpska riječ, god. XVII, br. 174, 27. avgust 1921, 2.

42 Narod, god. I, br. 34, 17. avgust 1921, 1.

43 Glas naroda, god. I, br. 38, (Sarajevo), 15. jun 1919, 1.

44 O podizanju spomenika u Otoci: Narodno jedinstvo, god. I: br. 24, 26. novembar 1918, 3; br. 53, 24. decembar 1918.

45 Milorad Ekmečić, Ustanak u Bosni 1875-1878, (Sarajevo: Veselin Masleša, 1973), 131-141, 183, 187, 197.

46 Bosanska vila, god. XVIII, br. 13. i 14, (Sarajevo), 30. jul 1903, 233-237.

47 Bosanska vila, god. XIX, br. 22. i 23,31. decembar 1904, 401-404.

48 Narodno jedinstvo, god. I: br. 35, 6. decembar 1918; br. 43, 14. decembar 1918. 
nije stigao zakoračiti u grad, a povodom njegove smrti, Pravda, list Jugoslovenske muslimanske organizacije, priznaće „njegove herojske borbe za slobodu“ i da je „u svemu bio je velik i u svojim vladarskim osnovama. San najdalekovidnijih i najumnijih sinova našeg troimenog naroda On je pretvorio u stvarnost“, pa će zato „zauvijek ostati u našim srcima i u našim dušama živjeti, jer „na vik on živi, ki zgine pošteno“. ${ }^{49}$ Hrvatska sloga je navela: „Baš mi, koji još uvijek tražimo Pravdu u ovoj zemlji, imamo i previše razloga tužiti nad gubitkom Pravednika (...) Povreda poštivanja Hrvatstva nije samo povreda dubokih stoljetnih osjećanja milijona duša, nego je ujedno povreda Pravednosti, one Pravednosti koju je cijelog života htio i tražio i za nju se borio naš Veliki Otac, Ujedinitelj i Kralj Petar I Kragjorgjević, najdostojniji nasljednik Tomislava, Zvonimira, Tvrtka i Petra Svačića. ${ }^{\text {"50 }}$ Sve nacionalne zajednice Sarajeva vidjele su dakle u njemu pravednog vladara i borca za slobodu, što je bio i osnov konsenzusa oko ideje za podizanje spomenika.

Uskoro će širom Kraljevine početi nicati biste, spomen-ploče i spomenici posvećeni kralju Petru I. ${ }^{51}$ U Bosni i Hercegovini među prvima su akciju započeli Visočaci 1921. godine, a spomen-obilježja postavljena su u Varcar-Vakufu (Mrkonić gradu) (1924), Foči (1925), Travniku, Bugojnu, Prozoru (1925), Bosanskoj Gradišci (1926), Livnu, Donjem Vakufu (1927), a svi kipara Ivana Ekerta. Njegov kolega Stamenko Đurđević uradio je spomenik za Dobrljin (1924), a Sreten Stojanović za Nevesinje (1928), i Bos. Krupu (1929).

Monumentalni spomenik kralju Petru u Bijeljini (1937) izradio je vajar Rudolf Valdec, dok je kiparka iz Bosne i Hercegovine Iva Despić izvela nekoliko spomen-bista kraljeva Petra I i Aleksandra I u Mostaru, Banja Luci, Sarajevu, Visokom, Gračanici pored Doboja. Spomenici su takođe nicali i u selima - krajiškoj Ćorkovači, hercegovačkoj Dubici, te Severskom u rogatičkom srezu. Tuzlaci su, kao i Visočaci i Zeničani, smatrali primjerenijim da se spomenik podigne u vidu doma u kome će se vaspitati i izdržavati đaci. Jajce je takođe podiglo dom u čast kralja, dok je Višegrad dugo kuburio sa finansijama oko dovršenja doma. Sve istaknute vajare koji su

49 Pravda, god. III, br. 851 (323), 17. august 1921, (12. Zil hidže 1339), 1.

50 „Reflekcija nad odrom Kralja Petra“, Hrvatska sloga, god. III, br. 178, 19. kolovoz 1921, 1.

51 „Između 1923. i 1940, oko 215 obeležja spomenika ili memorijala posvećenih pokojnim vladarima podignuto je širom Kraljevine Jugoslavije. Nijedan od ovih spomenika nije preživeo“. Bojana Pejić, „Jugoslovenski spomenici: umetnost i retorika moći“, Monumenti - promenljivo lice sećanja, 11-28. juna 2012, (Beograd: Centar za kulturnu dekontaminaciju, 2012), 14. 
radili spomenike u vrijeme Kraljevine vlasti su angažovale i nakon II svjetskog rata iz drugačijih ideoloških potreba.

Memorijali su bili rađeni u različitim formama i veličinama: spomen-ploče, ${ }^{52}$ biste, stojeće figure, prikazi konjanika i reljefa, da bi se kasnije pojavili i spomen-objekti utilitarne namjene (škole, ${ }^{53}$ bolnice, sokolski i planinarski domovi). Čuvanje sjećanja na kralja odvijalo se i putem sokolskih sletova i nošenja štafete, ${ }^{54}$ preimenovana su pozorišta, ${ }^{55}$ društva, ${ }^{56}$ organizovane su godinama poslije posjete delegacija i đačke ekskurzije Oplencu, ${ }^{57}$ na godišnjice su polagani vijenci i paljene svijeće.

Vojska je sa druge strane u vlastitom aranžmanu podizala obilježja u čast kralju Petru. Ono što je bila inicijativa vojnih vlasti, za razliku od građanske, brzo je bilo završavano, kao u Mostaru i to još za života

52 Prilikom osvećivanja doma Kola srpskih sestara u Sarajevu je organizovano otkrivanje „spomen-ploče Nj. V. Blagopokokjnom Kralju Petru Velikom Oslobodiocu i dobrotvorki Srpskog naroda Mis Adelini Pavliji Irbi.“ Večernja pošta, god. IX, br. 2776, 11. septembar 1930, 5.

53 „Pod pokroviteljstvom Nj.V. Kralja, a za spomen 50-godišnjice četovanja velikog kralja Oslobodioca Petra I, kao vojvode Mrkonjića podiže se ovaj dom prosvete za potrebe: 4-razredne osnovne, te drvodeljsko-obrtne škole i tečaja za seoske domaćice." ABiH, Fond Kraljev dvor, fasc. 240, dok. br. 298, Dvor, 13. 4. 1926, Odbor za gradnju prosvetnog doma Petra Mrkonjića, predsjednik dr Branko Barać, sveštenik, a tajnik Mirko Vranešević.

54 Sletski odbor i delegati sokolskih župa koji su učestvovali na vidovdanskom sokolskom sletu 1934. godine odlučili su da 200 sokola nosi simboličku štafetu, zublju na grob Kralja Petra Oslobodioca. „Sa gorućom bakljom od Sarajeva do groba Kralja Petra“,Jugoslovenska pošta: 6. novembra 1933, 5; 19. decembar 1933. „Povodom ove svečanosti čitav grad je bio iskićen državnim zastavama, a zgrade u ulicama kojim je zublja zahvalnosti nošena bile u svečano rasvetljene i ćilimima iskićene. Ulicama kojima je zublja prošla stajale su ogromne mase sveta u špaliru." Izvještaji o situaciji u Drinskoj Banovini, knj. 2, (1932-1935), sabrao i uredio: Dr. Andrej Rodinis, (Sarajevo: Arhiv Bosne i Hercegovine, 2010), 420. Videti još: Manojlović Pintar, Arheologija sećanja, 278-279.

55 ABiH, Fond Kraljev dvor, fasc. 229, dok. br. 431, „Direkcija Narodnog banovinskog pozorišta 'Kralj Petar I Veliki Oslobodilac' u Banjojluci obaviše svečano otkrivanje biste Kralja Petra I, dar Nj. V. Kralja tome pozorištu“, 17. novembara 1937.

$56 \mathrm{ABiH}$, Fond Kraljev dvor, fasc. br. 109, dok. br. 80, Srpska čitaonica za prosvjećivanje i nacionaliziranje radnika i omladine u Novom Sarajevu moli da Srpsko pjevačko društvo dobije naziv Petar Veliki Oslobodioc, 4 decembar 1922.

57 Sarajlije na grobu Velikog Kralja. Delegacija Sarajeva položila je jučer na Oplencu srebreni vijenac na grob blaženopočivšeg kralja Petra Velikog Oslobodioca. Bivši predsjednik opštine dr Ibrahim Hadžiomerović, podnačelnik Petar Jurišić, g. dr Toma Popović i dr Prenj, predsjednik upravnog suda u Sarajevu položili su vijenac izrađen od čistog srebra koji je izradio Jovo Trifković, direktor Oblasne radionice za umjetne zanate u Sarajevu. Vijenac je bio postavljen na kadifu uokvirenu u zlatan okvir na kome je bilo ispisanao: Sarajevo. Nakon toga delegacija je otišla u Topolu, na vašar, pa u Aranđelovac. Jugoslovenska pošta, god. I, br. 97, 23. septembar 1929, 1. 
kralja, ${ }^{58}$ pa je mnogo prije spomenika u vojnom logoru u Travniku (1928) podignut u sarajevskom naselju Bakarevac, Velešići u krugu radionice za opravku i pretres municije artiljerijske radionice II armijske oblasti, pored puta koji je vodio od logora kralja Aleksandra nepun kilometar sjeverno. Spomen-kompleks je činio spomenik sačinjen od temelja u dva pravougaonika, na donjem „četiri plakete sa slikama relijevno izlivenim“ na četiri strane, a na gornjem pravougaoniku krune sa vijencima i kraljevim imenom. Autori reljefa su Marko Šimunković (prizor četovanja u Bos. Krajini), ujedno i autor kompozicije spomenika, ${ }^{59}$ Pavle Hajl, livac i modelar (prizor „Golgote kroz Arbaniju“ i prizor „Div u sliku Ujedinjenja“), Nikola Bodrožić, ${ }^{60}$ profesor I gimnazije („Puštanje roblja iz tamnica“, tj. Oslobođenje), koji je bio i autor biste koja se nalazila na vrhu spomenika. Spomenik je zauzimao centralnu poziciju kruga prečnika $12,5 \mathrm{~m}$, popločanog bronzanim i kamenim pločama u obliku kopalja, te mačeva od tvrdog impregniranog drveta, pa je čitava spomenička kompozicija predstavljala orden Karađorđeve zvijezde sa mačevima. ${ }^{61}$ Pozitivnu ocjenu spomen-kompleksa dao je hrvatski istoričar umjetnosti, konzervator i mecena Kosta Strajnić u Spomenici izdatoj prilikom njegovog osvećenja. Iz Spomenice se ponešto saznaje i o „brisanju“ prošlosti u Sarajevu, da je ovaj spomenik podignut na istom mjestu gdje se prije I svjetskog rata nalazila kamena piramida sa spomen-pločom nadvojvodi Leopoldu Salvatoru, inspektoru cjelokupne artiljerije, prilikom njegovog inspekcijskog putovanja sarajevskom garnizonu nakon aneksije 1908. godine. Novi spomenik, kralju Petru, otkriven je u „velikoj patriotskoj manifestaciji“, u prisustvu „10.000 ljudi““62

Sarajevo nije bilo nikakav izuzetak ni u organizovanju priprema za izgradnju spomenika - u svim mjestima koja su se toga latila one su imale ustaljene poteze i zajednički karakter.

Nakon inicijativa lokalnih vlasti ili društava slijedili su pozivi na javne ankete, sastanci, formiranje radnih odbora, dogovori i usaglašavanja, okupljanje stručnih žirija, raspisivanje konkursa, kao i višegodišnje prikupljanje materijanih sredstava za pokriće troškova.

58 Srpska riječ, god. XVII, br. 138, 13. jul 1921, 2.

59 Marko Šimunković, vajar, stručni učitelj sarajevske zanatlijske škole, karijeru započeo u Zagrebu u vrijeme tamošnjeg boravka Vlahe Bukovca.

60 Nikola Bodrožić, đak Ivana Meštrovića, koga je kao dječaka ovaj poveo u Pariz i gdje je radio pod njegovim nadzorom. Kasnije se školovao u Pragu i završio skulptorsku specijalku na tamošnjoj akademiji. Spomenica svečanog otkrivanja spomenika Nj. V. Blaženopočivšem kralju Petru Velikom - Oslobodiocu, 6-17.

61 K(osta) Kulišić, prof, „Spomenik Kralju Petru“, Srpska riječ, br. 53, mart 1923, 2.

62 Večernja pošta, god. II, br. 707, (Sarajevo), 12. novembar 1923, 7 
U čitav proces bila je uključena i javnost - opštinske vlasti, stručnjaci, ${ }^{63}$ društva, ${ }^{64}$ pojedinci su iznosili ideje, polemike su objavljivane $u$ štampi, tokom godinâ donošeni su planovi i odluke, prihvatani, mijenjani ili napuštani, u skladu sa izmjenjenim političkim prostorom, snagom političkih arbitara ili reakcija na državne intervencije.

Cjelokupnom akcijom sve vrijeme je rukovodio radni odbor, uz manje izmjene u prvobitnom sastavu, izabran 5. oktobra 1921. godine ${ }^{65}$ na konstituirajućoj sjednici, kome su na želju Gradske opštine pridruženi 1930. još gradonačelnik i oba podgradonačelnika (Asimbeg Mutevelić sa dr Dušanom Jeftanovićem i dr Ivanom Pavičićem), ${ }^{66}$ uz nadzorni odbor sastavljen od predsjednika kulturnih društava Prosvjete (dr Savo Ljubibratić), Napretka (Ante Alaupović), Gajreta (dr Avdo Hasanbegović) i Benevolencije (dr Jakob Kajon). ${ }^{67} \mathrm{Na}$ toj je sjednici donešen zaključak da se „ovaj spomenik ima podići za čitavu Bosnu i Hercegovinu, a ne samo za grad Sarajevo, pa da se i rad odbora ima u tom smislu proširiti na čitav teritorij ovih zemalja“. Mada, Gradsko vijeće će i ostati i najveći donator ove

63 Sekcija Udruženja inž. i arh. protestovala je zbog nestručnog žirija. „Nakon toga je u žiri ad hoc uključen arh. Hugo Ehrlich, profesor tehničkog fakulteta u Zagrebu koji je predložio projekat arh Pičmana iz Zagreba, koji nije prihvaćen jer je predviđao podjelu trga na dva dijela, dok bi Sarajevo trebalo na tom mjestu samo veliki trg za zborovanje.“ Potpisnik teksta D. Grabrijan je smatrao najuspjelijim projekat „jednog našeg arhitekta, koji inače živi u Parizu", te predlaže publikaciju projekata i stručnu diskusiju iz Zagreba. „Oko regulacije trga Kralja Petra“, Jugoslavenski list, god. XVIII, br. 89, 14. april 1935, 6.

Ing. Marcel Martinis, „O budućem trgu i spomeniku Kralja Petra I. Oslobodioca“, Jugoslovenski list, XVII, br. 11, 14. januar 1934, 10.

64 Društvo prijatelja umjetnosti Cvijeta Zuzorić dalo je svoj prijedlog za trg kralja Petra Oslobodioca, da se postavi paviljon elipsastog oblika oko kojega bi bili „reljefi sa momentima iz naše najslavnije istorije“. Prijedlog je odbijen u opštini kao prevelik i skup. Jugoslovenska pošta, god. IX, br. 2378, 26. mart 1937, 5.

65 Za počasne članove izbrani su: kraljevski pokrajinski namjesnik dr Nikola Đurđević, komandant armije general Milisavljević, Gligorije M. Jeftanović, mitropolit Petar Zimonjić, reis-ul-ulema Hadži Mehmed Džemaludin Čaušević, biskup dr Ivan Šarić, franjevački provincijal fra Bonifacije Vidović, nadrabin jevrejske sefardske bogoštovne opštine dr Moris Levi, nadrabin aškenaske bogoštovne opštine dr Samuel Weszel, evang. župnik Johann Ludvig Sohafer, narod poslanik dr Milan Srškić, predsjednik trgovačke komore Nikola Berković, ministar dr Mehmed Spaho, ministar dr Hamdija Karamehmedović, narodni poslanik dr Ivan Pavičić, narodni poslanik Stjepan Janković. ABiH, OPSKP, kut. 1, dok. 13/1921. Odboru će se 1937. godine pridružiti Edhem Bičakčić, gradonačelnik, dr Miloš Ljeskovac, podnačelnik, dr V. Besarović, predsjednik Prosvjete, i Jelić. ABiH, OPSKP, kut. 2, dok. 21/1936.

66 Jugoslovenska pošta, god. II, br. 278, 24. april 1930, 3.

67 Članovi nadzornog odbora su se mijenjali smjenom na predsjedničkim mjestima ovih društava. Ovo je sastav iz 1930. godine. 
akcije. Na sljedećoj sjednici, od 22. oktobra, usvojen je nacrt za odborski rad u obliku poslovnog statuta, u kom je naznačeno da će glavni rad biti prikupljanje novčanog kapitala, koje će se vršiti preko sreskih (kotarskih) pododbora, a u manjim mjestima preko povjerenika. Zaista, arhiva Odbora pokazuje agilnost povjerenika i popise prilagača, pojedinaca, institucija, industrijskih preduzeća i banka iz brojih mjestima Bosne i Hercegovine. Odziva takođe nije bilo u zadovoljavajućoj mjeri u velikom broju mjesta, jer je u njima bila „povedena separatna akcija“ za podizanje spomenika.

Plan je bio da se prilozi ulažu u novčane zavode, dok dosegnu potrebnu visinu i da će se apelisati i „na pripadnike ovih zemalja, koji borave izvan njih, a primaće se prilozi iz cijele naše države“. ${ }^{68}$ Međutim, deset godina nakon formiranja odbora još ni zemljište predviđeno za podizanje trga i spomenika nije otkupljeno, niti je skupljeno dovoljno sredstava, ${ }^{69}$ oko trećine potrebne sume za pokrivanje troškova izgradnje trga i spomenika, pa je bilo prijedloga, u već izmijenjenim političkim okolnostima, „da se preko banovine izdejstvuje da svaka općina u Drinskoj banovini predvidi izvesnu svotu za spomenik u svome budžetu“" ${ }^{70}$

Srpsko kulturno društvo Prosvjeta je prvo dalo svotu u iznosu od 50.000 kruna i na taj način podržalo inicijativu za podizanje spomenika. ${ }^{71}$ Uslijedila je sjednica Gradske opštine na kojoj je donesen zaključak da se priloži milion kruna za podizanje spomenika kralju Petru odmah, a da se daljnih godina daje po milion kruna u tu svrhu. Ona će sve vrijeme biti glavni donator za izgradnju trga i spomenika, sa pet miliona kruna ili 1.250.000 dinara. ${ }^{72}$ Kada je tadašnji gradski komesar dr Ljudevit Novat ${ }^{73}$ sazvao sastanak izaslanika sarajevskih „kulturnih, humanitarnih i viteš-

68 Srpska riječ, god. XVII, br. 220, 28. oktobar 1921, 3. - Prilozi su stizali i od povjerenika iz Amerike, uglavnom srpskih. ABiH, OPSKP, kut. 1, dok. 48, 54, 85/1925.

69 Odbor je raspolagao sa 2,502.779 din, a u obećanju je bilo 220.719,48 din, svega 2,723.498,55 din. ABiH, OPSKP, kut. 1, dok. 60/1932, Zapisnik Odbora od 24. novembra 1932. godine.

70 Jugoslovenska pošta, god. III, br. 559, 1. april 1931, 5.

71 Srpska riječ, god. XVII, br. 171, 24. avgust 1921, 2. - Njihov primjer slijedila je i sarajevska crkvena opština sa 50.000 kruna. Srpska riječ, god. XVII, br. 176, 1. septembar, 1921.

72 Ostali najviši prilozi došli su od Državne hipotekarne banke, filijala u Sarjevu 808.198 din., Zemaljske banke 189.280 din., Srpske centralne privredne banke - u obveznicama u iznosu 42.440, 7.000 isplaćenih u gotovu, realizovano svega 50.204, Banke Gajret 45.720, Amerikansko-srpske banke 24.573, Bosanske industrijalne i trgovačke banke 17.600, u obveznicama 12.496, itd. ABiH, OPSKP, kut. 2, dok. 5/1941.

73 Dr Ljudevit Novat (1920-1922), pravnik, službu je vršio u Gračanici, Tuzli, Sarajevu i Beču. Od 1900. godine radio je kao politički pristav kod Zemaljske vlade u Sarajevu, da bi nešto kasnije obavljao dužnost policijskog nadsavjetnika Policijske direkcije u 
kih društava", na kome su se ovi izjasnili za spomenik koji treba da bude „vidan a ne kakva humana ili kulturna ustanova",74 predložio je da budući odbor riješi „na kakav način da se sabere svota novaca od 25,000.000 kruna, jer spomenik treba da bude lep i umetnički izrađen. Sarajevo ni u kojem slučaju ne treba da izostane iza drugih gradova. ${ }^{175} \mathrm{U}$ ovom, a i drugim donesenim zaključcima se ogledala ideja da se Sarajevo izdvoji kao centar oblasti, da mu se da važnost i da se akcija iskoristi za razvoj, a ne da bude osuđena na provincijske okvire.

O finansijskoj konstrukciji akcije i tokovima novca govori izvještaj bana P. Lukića ${ }^{76}$ iz naredne, 1937. godine, koji pominje prikupljenih ukupno 2,758.399 dinara, koji su deponovani kod raznih banaka, ali iskazuje i zabrinutost jer „od navedenih banka i novačnih ustanova nalaze se sledeće pod zaštitom i to: Srpska zadružna banka, Prva Hrvatska štedionica, Srpska centralna privredna banka i Bosanska industrijska banka", tako da je suma od 976.590 din. uložena kod ovih banaka „prema tome dovedena u pitanje“. U svom zaključku napominje: „Po svemu mi izgleda da u rukovanju ovom zamašnom sumom narodnog novca, naročito davanjem pojedinim gore pomenutim zavodima i prikupljanjem interesa od 1923. god. nije sve u redu te bi bilo potrebno da se iz Glavne Kontrole uputi stručno lice da izvrši pregled celokupnog rukovanja ovim novcem i da preuzme mere za osiguranje od naroda sakupljenog novca." Naglašava da je i „veoma sumnjivo da je pre 13 godina novac sakupljen u tako velikoj sumi, da se od tada više novac ne prikuplja, niti spomenik podiže, kao i to, da novac nije dat na priplod Hipotekarnoj Banci, no privatnim zavodima i ako o tome postoje izrična naređenja. 0 ovome se u poslednje vreme živo diskutuje naročito u krugovima ovdašnjih Srba nacionalista, te nalazim, da bi stanje ovoga Odbora bez obzira na ličnosti, koje su u istom trebalo što pre rasčistiti i ostvariti podizanje spomenika. Neostvarenje tako plemenitih namena gde je narod dobrovoljno dao svoju leptu i razlog je, što ovdašnji građani nerado daju svoje priloge u makakve svrhe. ${ }^{477} \mathrm{U}$ samom od-

Sarajevu. Nakon rata bio je imenovan u prvo Narodno vijeće Sarajeva, a nešto kasnije unaprijeđen je za vladinog savjetnika. Gradonačelnik Sarajeva je 1920-1922. godine.

74 „Odvojeno mišljenje nekih govornika, da bi se podignula zgodna humanitarna institucija sa vidnim spomenikom nije usvojena“, Srpska riječ, god. XVII, br. 190, 20. septembar 1921, 3.

75 Srpska riječ, god. XVII, br. 186, 15. septembar 1921, 3; Narod, god. I, br. 44, 21. septembar 1921, 2; br. 45. 24. septembar 1921, 2.

76 Ban Predrag Lukić bio je na čelu Drinske banovine u periodu od 31. maja 1935. do 9. decembra 1937. godine.

77 Opština grada Sarajeva raspolagala je sa 2,385.000, Srpska zadružna banka sa 557.800, Državna hipotekarna banka u Sarajevu 267.411, Srpsko-amerikanska 
boru je bilo diskusija oko odgovornosti za propadanje novca i mišljenja da se novac mogao podići prije donošenja navedenog zakona o storniranju zemljoradničkih dugova, pa je jedan od zaključaka bio da su „svi krivi moralno, a najviše predsjednik“, koji je bio i predsjednik uprave Srpske zadružne banke, u kojoj je naviše novca i propalo. ${ }^{78}$

Značajnije je ipak da je najveća suma bila deponovana kod opštine, odnosno da je glavninom novca za navedenu akciju raspolagalo opštinsko vijeće. Za svaku raspodjelu i ulaganje novca bio je potreban dogovor članova vijeća, prisutnih na osnovu trenutno postojećih stranačkih snaga, što govori nanovo o potrebi političkog konsenzusa za bilo koju akciju u gradu. Sliku političkog nereda upotpunjuje činjenica da je Gradsko vijeće tek novembra 1940. godine popunjeno hrvatskim članovima, nakon njihove 14-godišnje političke apstinencije. Gradsko vijeće je bilo politička pozornica Kraljevine u malom u kojoj je sa početničkim entuijazmom prihvaćena politička ideja „troimenog naroda“ i njihovog zaštitnika, a koja se potom sa političkim sukobima i njihovim krešendom sve više kompromitovala, da bi sa šestojanuarskom diktaturom bila kraljevom intervencijom preoblikovana u jugoslovenski unitarni pokušaj. Nakon brzog i bolnog poraza, na političku scenu je stupila sredinom tridesetih godina dirigovana politička konstrukcija Jereze, u praksi potpuno neproduktivna, sa tendencijom da uništi i ono malo političke korektnosti u bosanskohercegovačkom društvu.

Gledajući u tom smislu djelovanje Odbora, moglo bi se reći da je on bio jedna od oaza nekadašnjeg tananog, a ipak konstantnog napora da se dođe do zajedničkog stava. Njegova struktura govori o najuglednijim ličnostima grada, politički i privredno najjačim, iskazuje njihovu dominantnu poziciju u vlastitim vjersko-nacionalnim zajednicama, politički suprotstavljenim, ali predstavlja tradicionalnu sliku urbane zajednice Sarajeva. Njihova pozicija u odboru, kao i metoda djelovanja u akciji podizanja spomenika kralju bila je odraz vrijednosti pojedinih vjersko-nacionalno-političkih zajednica urbane strukture i njihove političke kulture, prema kojima se može mjeriti razvoj ove urbane sredine. Govor urbane elite je uvijek definisao vrijednosti i bio karakteristika odnosa realne moći u gradu. U ovom slučaju, našavši se pred zajedničkim zadatkom, opet se po

banka 233.916, Prva Hrvatska štedionica 157.200, Srpska centralna privredna banka u Mostaru 115.507, Bosanska industrijalna banka 27. 674 dinara, a napominje i dugovanje Kraljevske banske uprave u iznosu od 150.000 dinara. ABiH, fond Milana Stojadinovića, fasc. 48, kut. 2, dok. br. 287, Izvještaj bana Predraga Lukića od 5. januara 1937. godine.

ABiH, OPSKP, kut. 2, dok. 60/1932. 
ko zna koji put iskazala racionalnost, dominanta u njihovom djelovanju, kako u ekonomisanju vremenom tako i materijalnim izvorima, te pronicljivost i visok stepen umješnosti i obazrivosti u haotičnim političkim prilikama, u kojima su sigurno bili pojedinačno pritisnuti intervencijama, sugestijama ili vlastitim stajalištima. Usmjerenost ka budućnosti nije im dozvoljavala ishitrene korake, a do nje je valjalo doći dobro isplaniranim i taktičkim potezima.

Tako je ideja o uređenju trga Osloboditelja sa spomenikom išla u svojoj realizaciji posve laganom uzlaznom linijom, da bi gradonačelnik Ethem Bičakčić maja 1937. odobrio dodatna sredstva za završenje akcije. ${ }^{79}$ Tih dana je, na međunarodnoj izložbi umjetnosti i tehnike u Parizu, između dva najupadljivija paviljona, njemačkog i sovjetskog, postavljena u španskom paviljonu Pikasova Gernika.

Pola godine kasnije, januara 1938, Odbor je objavio konkurs za skicu spomenika. ${ }^{80}$ Ocjenjivački sud su sačinjavali: Ivan Meštrović, skulptor, njegov zamjenik Anto Alaupović, predsjednik Napretka, Veljko Petrović, načelnik umjetničkog odjeljnja Ministarstva prosvjete, njegov zamjenik dr Avdo Hasanbegović, predsjednik Gajreta, inž. Miloš Skakić, predsjednik Udruženja inžinjera i arhitekata, njegov zamjenik inž. arhitekta Dušan Smiljanić, inž. Đ. Božić, šef Građevinskog odjeljenja Gradske opštine, njegov zamjenik inž. arh. Mato Bajlon, dr Niko Andrijašević, bivši predsjednik Udruženja prijatelja umjetnosti, njegov zamjenik dr Vojislav Besarović, predsjednik Prosvjete, Ethem Bičakčić, načelnik Gradske opštine, njegov zamjenik dr Miloš Ljeskovac, podnačelnik Gradske opštine, Tanasije Ikonić, predsjednik Srpsko-pravoslavne crkvene opštine; njegov zamjenik Stevo Prnjatović, potpretsjednik SPCO, Fehim ef. Spaho, naib muslimanske vjerske zajednice, njegov zamjenik Ethem Mulabdić, predsjednik Uzdanice, Šćepan Grđić, predsjednik Odbora za podizanje spomenika, njegov zamjenik dr Jakov Kajon, predsjednik Benevolencije. ${ }^{81}$

Nakon pregleda pristiglih 30 radova, izabrano je sedam koji su došli u obzir za tri prve nagrade i dva otkupa. Prema gotovo jednogla-

79 ABiH, OPSKP, kut. 2, dok. 22/1937.

80 O idejama Odbora kako da izgleda spomenik i uslovima navedenim u konkursu, predsjednik Odbora se konsultovao sa Veljkom Petrovićem, tadašnjim načelnikom umjetničkog odjeljenja ministarstva prosvjete, dr Bogadanom Popovićem, profesorom Beogradskog univerziteta, „najvećem autoritetu na polju estetike“ $\mathrm{i}$ „o kojem se je i sam Meštrović tako laskavo izrazio“, kao i sa A. Meštrovićem. ABiH, OPSKP, kut. 2, dok. 51/1937, Pismo Š. Grđića A. Meštroviću, 6. decembra 1937.

81 Jugoslovenska pošta, god. X, br. 2614, 4. januar 1938, 5. 
snoj odluci žirija, uz samo jedan izdvojen glas, prva nagrada, sa 40.000 dinara, pripala je Franu Kršiniću, ${ }^{82}$ kiparu iz Zagreba, „koji je svoje visoke umjetničke sposobnosti i savjesnost dokazao mnogim dosadašnjim svojim radovima, kao i izradom modela za ovaj spomenik“. ${ }^{83}$ Drugu nagradu su podijelila idejna rješenja Antuna Avgustinčića sa saradnikom arhitektom Dragom Galićem i Ive Lozice i njegovog saradnika arhitekta Nevena Šegvića. ${ }^{84}$ Treću nagradu su podjelila četiri projekta, dok su njihovi ugledni konkurenti ostali bez nagrade. ${ }^{85}$

Ugovor sa Kršinićem potpisan je 28. septembra 1938. i njim je dat rok od dvije godine za postavljanje spomenika, a u tu svrhu je predviđeno dva miliona dinara. Juna 1939. stigli su za izradu postamenta ogromni blokovi gabro-granita iz Jablanice („od istog kamena od koga je izgrađen spomenik neznanog junaka na Avali“, ali ne crne, nego sive boje) i instalirane su barake sa mašinama za rezanje kamena i izrađivanje reljefa za spomenik, koje je radio vajar Ivan Lozica ${ }^{86} \mathrm{Na}$ jednoj strani postamenta nalazili su se reljefi sa motivima Balkanski rat, Golgota i Kapija slobode Kajamčalan, a sa druge strane spomenika reljefi „iz predoslobodilačkog života“ i to Ustanak („Petar Mrkonjić među ustašama u planini Ćorkovači“), Zakletva na ustav (poslije izbora za kralja) i Krunisanje („sa siluetom crkve u Žiči“). Nacrtom spomenika je predviđeno da će „od vrha postolja do vrha krune iznositi pet i po metara, za čitav metar više nego Jelačićev

82 Frano Kršinić (Lumbarda, 1897- Zagreb,1982) akademiju je završio u Pragu 1921. godine. Nakon studijskih putovanja po Evropi i dvogodišnjeg boravka u Beogradu, nastanjuje se u Zagrebu. Jedan je od osnivača grupe Zemlja, te član grupe Nezavisnih. Od 1924. profesor je na Akademiji, a od 1947. vodi majstorsku radionicu u Zagrebu. Član je JAZUod 1949. godine.

83 Kršinić je do tada već postavio statuu Pučka pjevačica (Ilidža, 1929), a nakon rata to će biti Majčina igra (Sarajevo, 1946). Pored toga, u sarajevskom parku pored Miljacke nekoć se nalazio brončani kip Njegovateljica ruža, koji se sada nalazi u Zavodu za zaštitu spomenika. Na Ilidži je postojao (prije ovoga zadnjeg rata) i kip Majčina igra (izrađen 1962. a nestao 1994) te kip Djevojka plete kosu (također na Ilidži). Za bosanske franjevačke crkve Kršinić je izradio nekoliko kipova. Za sarajevsku crkvu Sv. Ante izveo je Gospu s Djetetom. Franjevački medijski centar Svjetlo riječi, datum pristupa 25. 11. 2015, http://www.svjetlorijeci.ba/clanak/1581/likovna-umjetnost/njezni-snovi-u-kamenu-frano-krsinic-1897-1982

84 ABiH, OPSKP, kut. 2, dok. 53/1938.

85 Ivan Radauš, inž. Frane Cota sa prof. O. Mujadžićem, Ilija Kolarović, Ivan Ekert, Tine Kos, Marko Brežanin, Sreten Stojanović neki su od autora prijavljenih skica.

86 Ivan Lozica (Lumbarda,1910-1943), na preporuku svog mentora, kipara Frana Kršinića, 1926. kao prvi u klasi, primljen je sa šesnaest godina u klasu Ante Meštrovića na Likovnu akademiju u Zagrebu, Specijalizirao je kiparstvo na Sorboni. Nakon povratka bio je profesor na istoj akademiji. U Meštrovićevu ateljeu u Splitu izrađivao je karijatide za njegov „Spomenik neznanom junaku“ na Avali u Beogradu (1935-38). 
trg u Zagrebu i knez Mihailov u Beogradu. Tome još treba dodati podignutu ruku sa skiptrom, što će iznositi još jedan metar. Ova visina uzeta je s obziroma na veličinu trga, koji je veći od Jelačićeva trga u Zagrebu i knez Mihailova u Beogradu. Prema spomeniku je udešeno i postolje. Čitava visina postolja i spomenika do vrha krune iznosiće trinaest metara. Ako se uzme u obzir da su zgrade koje okružuju trg od sedamnaest od dvadeset metara visina, i da će spomenik biti na sredini trga, onda je jasno da će se Kralj Petar na spomeniku vidjeti, sa svakog mjesta trga i susjednih ulica, na horizontu, iznad tih zgrada, jer je visina spomenika znatno veća od polovice visine svih tih zgrada. Jedino, kad se spomenik pogleda prema zvoniku crkve vidjeće se iznad njega gornji dio zvonika. I zelena aleja, kada dobro poraste u visinu, biće na horizontu iznad visine spomenika." ${ }^{87}$ Sam spomenik je, kako štampa navodi, u mozaiku istorijskih građevina i spomenika Sarajeva trebao biti „najljepše zrnce, upravo alem kamen“. Svojim dimenzijama i okolinom trebao je predstavljati „najširi i najveći trg u državi, a po svoj prilici i na Balkanu“.88

Svi dijelovi za spomenik, konjaničku figuru kralja Petra I Velikog Oslobodioca bili su 21. oktobra 1940. dopremljeni u Sarajevo i to odmah na prostor budućeg trga, pored tih dana postavljenog postolja, na koje je dizalicom u naredne dvije sedmice montiran spomenik, pod nadzorom Kršinića. Svečano otkrivanje je planirano za 6. septembar 1941. godine, simbolično izabran datum, dan punoljetstva budućeg kralja Petra II, unuka blaženopočivšeg Petra Oslobodioca, kada će preuzeti kraljevsku vlast u svoje ruke. U tom momentu još uvijek nesređen, $\operatorname{trg}^{89}$ je raščišćen zaslugom gradonačelnika Muhameda Zlatara ${ }^{90}$ tek sredinom februara 1941. i spomenik je dobio prostor da "diše",91 ali ne zadugo.

Završnica akcije podizanja spomenika se odvijala kada su ratne trube već uveliko zaglušivale evropski prostor. Uvlačenje Jugoslavije u interesni prostor Njemačke, dolazak Italije i na južne granice države sa aneksijom Albanije aprila 1939. podudarali su se i sa unutrašnjim

87 Jugoslovenska pošta, god. XI, br. 3116, 25. august 1939, 5; Grđić, „Spomenik Kralja Petra Oslobodioca", 44-46.

88 Jugoslovenska pošta, Sarajevo, br. 3472, 23. oktobar 1940, 4.

89 Sudski sporovi su bili u posljednjoj instanci. Jugoslovenski list, br. 252, 24. oktobar 1940, 5. Konačno, v. d. predsjednika Gradske opštine Zlatar je raspisao licitaciju za poslove rušenja zgrada. Bašagićevu kuću u kojoj se nalazila knjižara vakuf je srušio u svojoj režiji. Jugoslovenski list, br. 287, 4. decembar 1940, 5.

90 ABiH, OPSKP, kut. 2, dok. 12/1941, Pismo zahvalnosti Muhamedu Zlataru, vršiocu dužnosti gradskog načelnika 30. januara 1941. godine na predusretljivosti koju je pokazao.

91 Jugoslovenska pošta, br. 3567, 14. februar 1941, 4 
sve agresivnijim desničarskim pomjeranjima koja su se nastojala okončati sa sporazumom Cvetković-Maček augusta 1939, a što se u praksi pokazalo zakašnjelom intervencijom. U samom gradskom vijeću posljedica dugogodišnje neuspješne nacionalne politike ogledala se u neizbalansiranoj politici vladajuće Jugoslovenske radikalne zajednice, kao i u 14-godišnjoj apstinenciji Hrvata iz ovog najvažnijeg upravnog gradskog tijela. ${ }^{92}$

Možda se u tom momentu činilo da, kako je vrijeme odmicalo, spomenička slika kralja predstavlja ipak neko uporište i simboličnu metaforu stabilnosti u tim za grad predapokaliptičim vremenima, opterećanim još neizvjesnijom budućnošću, pred prijetećom destrukcijom ionako krhke zajednice, surovo nagovještenu vjestima o destrukciji drugih evropskih urbaniteta. Pokušalo se, pomiješanih osjećaja, simbolikom spomenika pozivati na simbol jugoslovenstva, ne kao već propale ideologije nacionalnog jedinstva, nego u tom momentu ugrožene državne granice. Simbolika spomenika kao zaštitnika svih građana je, nakon gotovo dvije decenije, ponovno dobila na značaju, ali i u grčevitoj završnici ostala poražena.

Sa novoformiranom Nezavisnom Državom Hrvatskom i ustaškim režimom, u kome je prošlost prethodne državne zajednice bila sistematski brisana, postupci novoformirane vlasti i njeno zvanično nasilje i nad pamćenjem bili su temeljiti u uklanjanju svih njenih tragova. Dinastički spomenici su bili samo dio te pozamašne i brze akcije i na prostoru Bosne i Hercegovine. Maja 1941. Gradska opština se obratila Frani Kršiniću, „koji je u svoje vrijeme izradio i postavio spomenik kralja Petra I, na trgu pred Gradskom tržnicom, s obzirom na umjetničku vrijednost izrađenih reljefa, da se primi demontiranja spomenika, koji će se pohraniti u Zemaljskom muzeju u Sarajevu. Na poziv Gradske općine, akademski kipar g. Frane Kršinić pristao je da poduzme radove na demontiranju spomenika i postavio uvjete po kojima će taj posao izvršiti. Kako su uvjeti prihvatljivi, demontiranje spomenika kralja Petra I, koji nije dočekao ni dugo pripremano otkriće, izvršit će se u skoro vrijeme “.93

Na mjestu spomenika kralju Petru Karađorđeviću bio je postavljen njemački spomenik sa prepoznatljivim znakom V (victory), zapaljen

92 „U sadanjem vijeću sjede od Srba ljudi, koji za punih pet godina nisu dokazali da su umjeli da zastupaju dobro ni interese Srba ni opšte interese ovoga grada. A čini mi se, da i među muslimanima postoji prilično nezadovoljstvo sa sadanjim njihovim pretstvnicima, mada je većina muslimana u istom partijskom taboru." Jugoslovenska pošta, br. 3476, 28. oktobar 1940, 4.

„Odstranjenje spomenika Petra I“, Sarajevski novi list, br. 9, 21. svibnja 1941, 5. 


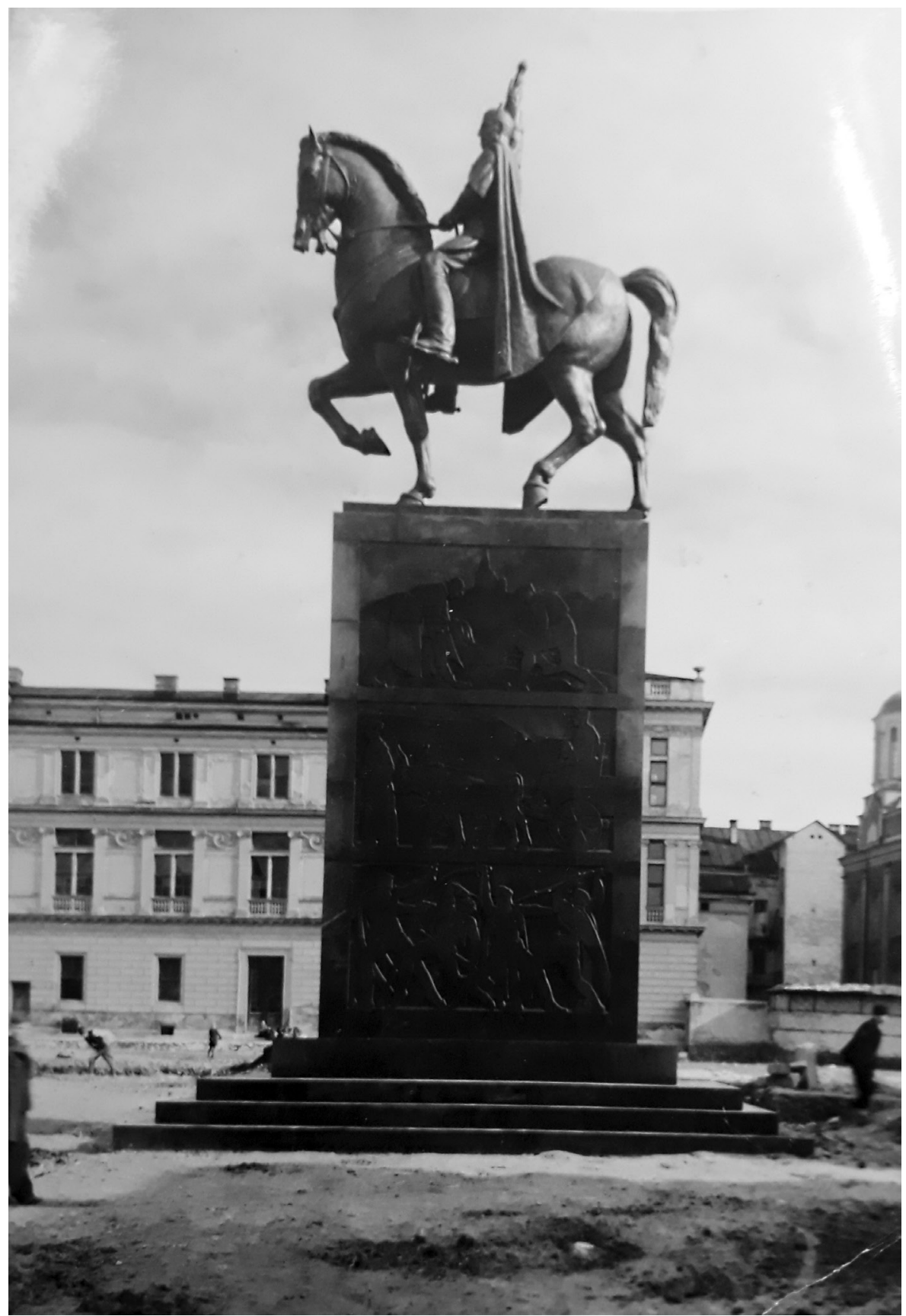

Spomenik Kralju Petru I Karađorđeviću u Sarajevu (ABiH, Fond OPSKP, kut. 2, foto 17) 
i srušen 1945. godine, ${ }^{94}$ tako da je i taj simbol preuranjene samouvjerenosti uklonjen sa novim ideološkim poretkom i dirigovanim sjećanjem. Spomenik kralju Petru Karađorđeviću već je bio izgubljen iz sjećanja, kao dio politike temeljnog i sistematskog zaborava i nove kulture, a samim tim akcija oko njegovog podizanja, kao izraz kolektivne, urbane senzibilnosti i takta, ali je u nazivu trga ostalo - oslobođenje. ${ }^{95}$

\section{Rezime}

Možda se dugotrajna, dvodecenijska akcija Odbora za podizanje spomenika kralju Petru I Karađorđeviću Oslobodiocu u Sarajevu može činiti čudnom, iznenađujućom, s obzirom na veliki broj podignutih spomen-obilježja kralju Petru u Bosni i Hercegovini tokom međuratnog perioda, ali ona govori o Sarajevu, oličenom u Odboru, koji predstavlja istinski „spiritus urbanitatis“ jedne tradicionalne urbane sredine u kojoj se nije dozvoljavalo da konflikt prekine svakodnevni tok života/suživota, u kojoj se poštovalo pravo na drugačiji politički izbor i moralnu autonomiju, u kojoj je postojala „posebna disciplina prešućivanja i podrazumijevanja“.

Konsenzus elite Sarajeva, čiji je između ostalog domen bio i kolektivno pamćenje, bio je u tome da kralj Petar Karađorđević nije dio njihovog kolektivnog pamćenja, niti se njegov spomenik nužno treba postaviti u javni prostor grada kao zajedničko dóbro, zajednička prepoznatiljiva vrijednost za cjelokupno građanstvo. Kralj Petar nije bio prepoznat kao dio njihovog zajedničkog, urbanog identiteta. Pri tome se njihova građanska lojalnost iskazala u nizu operativnih postupaka i postepenom djelovanju, paritcipaciji svih vjersko-nacionalnih elita u formiranju odbora, traženju

94 Amra Čusto, „Spomenici i identiteti na primjeru sarajevskog trga Oslobođnja 'Alija Izetbegovic'”', Identitet Bosne i Hercegovine kroz historiju, zbornik radova, 2, (Sarajevo: Institut za istoriju, 2011).

95 „Na posljetku, pošto je trg okružen ulicama: Kralja Petra, Prestolonasljednika Petra i Petra Preradovića, pa će i kuće u tim ulicama imati brojeve i naziv tih ulica, i ako na tom mjestu gledaju na trg, molimo Vas da izdjejstvujete kod Gradske općine, da ovoj ulici, koja će se prosjeći od ulice Kralja Petra do ulice Prestolonasljednika Petra, ne daje posebnog imena, nego da se na toj strani metne: 'Trg Oslobođenja', jer i tako ta sva ulica pripada trgu.

Uvjereni da ćete se ovoj želji odbora odazvati, i u ovome izaći mu u susret, kao što ste i do sada činili, zahvaljujemo se na pripravnosti koju pokazujete u pogledu podizanja trga. Iz sjednice Odbora za podizanje spomenika Nj. V. Blagopokojnom Kralju Petru Prvom Velikom Oslobodiocu, držane 30. januara 1941." ABiH, OPSKP, kut. 2, dok. 12/1941, Pismo zahvalnosti Odbora Muhamedu Zlataru, vršiocu dužnosti gradskog načelnika. 
pogodnog mjesta za spomenik, raspisivanju konkursa itd. Međutim, interesno, emocionalno i u kranjoj liniji racionalno nepristajanje na podržavanje političkog sistema koji se pokazao nestabilnim, u kojem su promjene u strukturi i dinamici političke moći bile dirigovane i čime su se politički ideali s kraja rata urušili, činilo ih je opreznim, njihovu akciju dugotrajnom i za njih i ekonomski isplativom.

Zajedničko dobro koje je odbor prepoznao moglo bi se iskazati sloganom „požuri polako“ (festina lente), pri čemu je urbana elita kao simbol grada, kao pobjednik života, u ovom slučaju i čuvar tradicionalno harmoničnih međusobnih odnosa, znala kada da ubrza a kada da uspori.

\section{Sources and Literature}

Arhiv Bosne i Hercegovine: Odbor za podizanje spomenika kralju Petru I u Sarajevu; Kraljev dvor.

- Arhiv Jugoslavije. Fond Milana Stojadinovića.

- $\quad$ Almanah adresar grada Sarajeva. 1937.

- Definitivni rezultati popisa stanovništva, Kraljevina Jugoslavija. Sarajevo, 1932.

- Grđić, Šćepan. „Spomenik Kralja Petra Oslobodioca u Sarajevu“. Kalendar Prosvjeta za godinu 1939. Sarajevo, 1939.

- Izvještaji o situaciji u Drinskoj Banovini, knj. 2, (1932-1935), sabrao i uredio: Dr. Andrej Rodinis. Sarajevo: Arhiv Bosne i Hercegovine, 2010.

- Spomenica svečanog otkrivanja spomenika Nj. V. Blaženopočivšem kralju Petru Velikom - Oslobodiocu, 11. XI 1923. Art radionica II armijske oblasti u Sarajevu, 11. novembra 1923. Sarajevo, 1923.

- Izmišljanje tradicije, ur. Erik Hobsbom, Terens Rejndžer. Beograd: Biblioteka XX vek, 2002.

- Jambrešić-Kirin, Renata. Dom i svijet. Zagreb: Centar za ženske studije, 2008.

- $\quad$ Ekmečić, Milorad. Ustanak u Bosni 1875-1878. Sarajevo: Veselin Masleša, 1973.

- Manojlović Pintar, Olga. Arheologija sećanja, spomenici i identiteti u Srbiji 1918-1989. Beograd: Udruženje za društvenu istoriju, Čigoja štampa, 2014.

- Čusto, Amra. „Spomenici i identiteti na primjeru sarajevskog trga Oslobođnja 'Alija Izetbegović'“. Identitet Bosne i Hercegovine kroz historiju, zbornik radova, 2, 229-238. Sarajevo: Institut za istoriju, 2011.

- Kučuk-Sorguč, Indira. „Prilog historiji svakodnevnica: Spomenik umorstva okamenjena prošlost na izdržavanju stoljetne kazne“. Prilozi 34, (Sarajevo), 2005. 
- Musabegović, Senadin. „Upotreba simbola i korištenje mita“. Dijalog, časopis za filozofiju i društvenu teoriju, 1-2, (Sarajevo), 2007. doi: 10.5644/ dijalog.2013.1-2.0

- Pehar, Dražen. „Urbani duh kompromisa i postdaytonska Bosna“. Forum Bosnae 5, (Sarajevo), 1999.

- Pejić, Bojana. „Jugoslovenski spomenici: umetnost i retorika moći“. Monumenti - promenljivo lice sećanja, 11-28. juna 2012. Beograd: Centar za kulturnu dekontaminaciju, 2012.

- Radenović, Sandra. „Nacionalni identitet, etnicitet, Kritička kultura sećanja“. Filozofija i društvo 31 (3), (Beograd), 2006.

- $\quad$ Bosanska vila, list za zabavu, pouku i književnost, Sarajevo.

- $\quad$ Bratstvo, list za vjersko i narodno prosvjećivanje, Sarajevo.

- Glas naroda, političko-informativni list, organ Demokratske stranke za BiH, Sarajevo.

- Hrvatska sloga, novine Hrvatske težačke stranke u Bosni i Hercegovini, Sarajevo.

- Jugoslovenska pošta, političko-informativi list, Sarajevo.

- Jugoslovenski list, političko-informativni list, Sarajevo.

- Kalendar Prosvjeta, narodni almanah, Sarajevo.

- $\quad$ Narod, političko-informativni list, Sarajevo.

- $\quad$ Narodno jedinstvo, službeni organ Pokrajinske vlade, Sarajevo.

- Pravda, Glasilo Jugoslovenske muslimanske organizacije, Sarajevo.

- Srpska riječ, Radikalni list, Sarajevo.

- Večernja pošta, političko-informativni list, Sarajevo.

- Acović, Dragomir. „Regalije“. Datum pristupa 31. 11. 2015. http://www. pokimica.com/lang_lat/tekst2_04_lat.htm

- $\quad$ Franjevački medijski centar Svjetlo riječi. Datum pristupa 25. 11. 2015. http://www.svjetlorijeci.ba/clanak/1581/likovna-umjetnost/njezni-snovi-u-kamenu-frano-krsinic-1897-1982

- Mitrović, Vladimir. „Dinastički spomenici u Kraljevini SHS/Jugoslaviji (1919-1941)“. Datum pristupa 24. 9. 2015. https://graditeljins.wordpress.com/2015/09/15/dinasticki-spomenici-u-kraljevini-shs-jugoslaviji-1919-1941/

- $\quad$ Mutnjaković, Andrija. „Arhitekt Josip Pičman“. Život umjetnosti 14, (Zagreb), 1971, 83. Datum pristupa 20.11. 2015. https://www.ipu.hr/content/zivotumjetnosti/ZU_14-1971_074-089_Mutnjakovic.pdf

- Pejić, Bojana. „Javni rezovi“. Datum pristupa 3. 5. 2011. http://www.kulturpunkt.hr/content/javni-rezovi 


\title{
Summary
}

Sonja Dujmović

\section{Urban Culture and Collective Memory - Monument in Sarajevo to King Peter the Great Liberator}

\begin{abstract}
The paper is an attempt to understand the reasons for the two-decade long project of the building the monument to King Peter I Karađorđević in Sarajevo.

KEY WoRDS: Monument, King Peter I Karađorđević, Sarajevo, Urban Culture, Collective Memory, Urban Elite, Consensus, Compromise
\end{abstract}

Perhaps the two decade-long campaign by the Committee for Building the monument to King Peter I Karađorđević, the Liberator, in Sarajevo may seem strange, even surprising, considering the large number of similar monuments to King Peter that had been built in Bosnia and Herzegovina during the interwar period. But this campaign speaks about Sarajevo, embodied in the Committee, which represented a true "spiritus urbanitatis" of a traditional urban settlement that did not allow conflict to break up the everyday course of life, where the right to a different political choice and moral autonomy was respected, and where a "special discipline of tacitness and implicity" existed.

The consensus of the Sarajevo elite, in whose domain was the collective memory, was that King Peter Karađorđević was not a part of their collective memory and that it was not necessary to build a monument to him in the city's public space as a common good, a common recognizable value for all citizens. King Peter was not accepted as a part of their collective urban identity.

Their loyalty was thereby shown in a number of operative actions and gradual activities, by the inclusion of all religious and national elites in the forming of the Committee, in the search of a suitable place for the monument, in the publishing of a competition, etc. However, the emotional and rational refusal to support the political system, which proved to be unstable, in which changes in structure and dynamics of political power were directed and which brought the political ideals from the end of the 
war crushing down, made them cautious, their action long lasting and economically viable for them.

The common good that the Committee recognized could be expressed by the slogan "make haste slowly" (festina lente), whereby the urban elite as the symbol of the city, as the winner of life in this case, and the keeper of traditionally harmonious relations, knew when to speed up, and when to slow down. 